\title{
Nota Técnica: \\ Aplicaciones y limitaciones del coeficiente $K$ de eficacia de la adición de escoria de horno alto en el hormigón
}

\author{
Technical Note: \\ Ground granulated blast furnace slag efficiency coefficient ( $k$ value) \\ in concrete. Applications and limits
}

\author{
M. A. Sanjuán ${ }^{(*)}$, A. Piñeiro(*), O. Rodríguez(**)
}

Recepción/Received: 1-VI-10

Aceptación/Accepted: 7-VII-10

Publicado online/Online publishing: 20-VI-11

\section{RESUMEN}

Recientemente se ha incorporado un valor del coeficiente de eficacia $\mathrm{K}$ para la escoria de horno alto en la norma europea EN 206-1:2000. Los valores propuestos en los grupos de trabajo eran muy diversos ya que en algunos casos sólo consideraban la resistencia mecánica para su determinación mientras que en otros se remarcaba la importancia de tener en cuenta, además, aspectos relativos a la durabilidad del hormigón con dicha adición.

En el presente artículo se discuten las ventajas y desventajas de proponer unos valores del coeficiente de eficacia $\mathrm{K}$ más o menos conservadores. La conclusión final se resume con la propuesta de una recomendación lógica que consiste en trasladar a cada país la elección del coeficiente $\mathrm{K}$ para que pueda aplicarse a los hormigones empleados en su territorio; tales valores de $\mathrm{K}$ deberán ser seleccionados de acuerdo con la experiencia de cada uno de los países.

Palabras clave: Coeficiente de eficacia $\mathrm{K}$, escoria granulada de horno alto, hormigón, EN 206-1, durabilidad.

\section{SUMMARY}

Recently, a k-value for ground granulated blast-furnace slag or $k$-value has been added to the revision of the European standard EN 206-1:2000. The proposed values during the disscusion in the working groups were very different because in most of cases the compressive strength was the only characteristic considered; while only in few cases the concrete durability was taken into account when ground granulated blast-furnace slag is added directly to the mix.

Advantages and disadvantages of the k-values found in the literature are discussed in this paper. The final conclusion may be summarised suggesting a logical proposal of addressing to each country the choice of the $k$-value in function of the concrete application, environment and placing conditions selected according to their own experience.

Keywords: k-value, ground granulated blast-furnace slag, concrete, EN 206-1, durability.

\footnotetext{
(*) Instituto Español del Cemento y sus Aplicaciones (IECA) (Madrid, España).

(**) Centro Nacional de Investigaciones Metalúrgicas (CENIM-CSIC) (Madrid, España).
} 


\section{INTRODUCTION}

The increasing use of additions in cements produced according to the european standard EN 197-1:2000 (1) or EN 197-1:2011 (in particular, silicious fly ash, V, natural pozzolan, $P$, and blast-furnace slag, $S$ ) and in the concrete produced according to Spanish regulation, EHE-08 (2) (In Spain, only direct addition of siliceous fly ash, $V$, or silica fume, $D$, is allowed) or according to EN 206-1:2000, has been promoted for environmental reasons in some cases because of the recycling of industrial wastes or by-products $(V, S$ and $D)$, and because of the economical interest in some other cases. These additions, employed by the cement and concrete industries, exhibit different characteristics, particularly, they present reactivities totally differents. This means that the reactivity ranges go from values corresponding to an addition traditionally considered as inert ${ }^{1}$ material such as limestone (named $L$ and $L L$ in the European standard EN 197-1), passing through additions whose reactivity is activated when they get in contact with alkaline components as is the case of natural pozzolans $(P)$ and siliceous fly ashes $(V)$, and finally, reaching the additions having some latent hydraulicity such as ground granulated blast-furnace slag (ggbs).

As previously said, additions may be incorporated in the Portland cements, which is the most recommendable option because in this case the addition quality is just controlled and guaranteed from the beginning and also the mix with clinker is optimized in order to get a high quality blended cement. In contrast, some additions can be added directly to the concrete as a type II addition in established proportions and procedures standarised in Europe by EN 206-1:2000 (1), considering the "equivalent performance" concept. This second way of use of the additions needs a quick and reliable procedure of characterization of the additions with regard to properties of the concrete made of them. This procedure is under discussion in CEN/TC 104/WG 15.

Currently, this is done by means of a simple and quick parameter which offers a relative value of the addition performance when it is added directly to the concrete, and thus, it serves as a guide to making the mix design of the concrete. Such parameters generally accepted is called "efficiency coefficient" or "k-value" and it takes different values depending on the addition considered. However, it should be taken into account that the same addition performs differently when curing conditions are changed from case to case.
The $k$-value is based on the comparison of the performance of a concrete with addition compared to another without it.

The "efficiency coefficient" concept of each addition is based on the "equivalent performance" concept (EPPC) where an effective water/binder ratio $(W /(C+A))_{\text {effective is }}$ defined. This ratio provides the same performance, i.e. the same characteristics, than a reference concrete with a water/cement ratio, $(W / C)_{\text {referencer }}$ and then [1] :

$(W / C)_{\text {reference }}=\left(\frac{W}{(C+A)}\right)_{\text {effective }}=\left(\frac{W}{(C+k \cdot A)}\right)[1]$

Where:

$K=$ Efficiency coefficient ( $k$-value).

$C=$ Cement content, $\%$ mass.

$W=$ Water content, $\%$ mass.

$A=$ Addition content, $\%$ mass.

The physical concept of this indicator may be explained as follow. Considering the same water content in both concretes, reference and concrete with an addition, a $k$-value of 0.4 , for instance, means that $1 \mathrm{~kg}$ of cement could be replaced by $2.5 \mathrm{~kg}$ of addition maintaining the same characteristics.

The "k-value" has been traditionally determined with regard to the concrete compressive strength in most research programmes. This $k$-value varies from 0.2 for some siliceous fly ashes $(V)$ in some cases, to more than 1.0 for silica fume in other cases.

Table 1 shows the $k$-values specified by the European standard EN 206-1:2000 and EHE-08 (Spanish regulation). Currently, EN 206-1:2000 is being revised and the proposal of including a "k-value" for ground granulated blast-furnace slag ( $g g b s$ ) has been accepted (Resolution 6 CEN/TC 104/SC 1 -Delft 2010-09-15/16-).

The "k-value" concept is coherent with the "equivalent performance" concept (EPPC), therefore, this parameter must cover not only the mechanical strength but also the durability of the concrete. This is an important point which is highlighted in the note of chapter 5.2.5.1 of EN 2061:2000. Because of strength is not a proxy for durability, a particular $k$-value for durability must be developed.

The idea of having a k-value for each addition is very attractive from the point of view of the user because it

1 Limestone reactivity has been studied in the PhD. Thesis by Thomas Matschei (Aberdeen University, United Kingdom): Thomas Matschei. Thermodynamics of cement hydration (2008). Academic supervisor: Prof. F. P. Glasser, Univ. of Aberdeen. 
Table 1

$K$-values according to EHE-08 and EN 206-1:2000.

\begin{tabular}{|c|c|c|}
\hline \multirow{2}{*}{ Addition } & \multicolumn{2}{|c|}{ K-values } \\
\hline & EHE-08 (Paragraph. 37.3.2) & EN 206-1:2000 (Paragraph. 5.2.5.2.) \\
\hline Silicious Fly Ash & $\begin{array}{l}0.20 \text { (CEM I 32.5) } \\
0.40 \text { (CEM I } 42.5 \text { y CEM I } 52.5)<0.65^{*} \\
\quad(\text { Maximum content of } V<30 \%)\end{array}$ & $\begin{array}{l}0.20 \text { (CEM I 32.5) } \\
0.40 \text { ( CEM I } 42.5 \text { and CEM I 52.5) } \\
\text { (Maximum content of } V<33 \%)\end{array}$ \\
\hline Silica fume $(D)$ & $\begin{array}{c}\leq 2 \\
=1(\mathrm{a} / \mathrm{c}>0.45 \text { and exposure class } \mathrm{H} \text { or } \mathrm{F}) .(\text { Maxi- } \\
\text { mum content of } D<10 \%)\end{array}$ & $\begin{array}{c}2 \\
=1 \quad(a / c>0.45 \text { and exposure class XC or XF). } \\
\quad(\text { Maximum content of } D<11 \%)\end{array}$ \\
\hline $\begin{array}{l}\text { Ground granulated blast-furnace slag } \\
\text { (ggbs) }\end{array}$ & 0 & $\begin{array}{c}\leq 0.6 \\
\text { (Maximum content of ggbs }<50 \% \text { ) } \\
\text { (Revision of the EN 206-1:2000) }\end{array}$ \\
\hline
\end{tabular}

- This value may be used when research results support the application and, also, it is supervised by the working site Head.

makes quite easy the use of additions incorporated directly to the concrete just from the beginning of the concrete mix design.

However, it is necessary to take into account that although the $k$-value is a practical and easy tool recognised in the current national regulations, as the EHE-08 in Spain, and the international standards as the European standard EN 206-1:2000, it is not possible to get as an unique and universal (global) kvalue for any addition or property considered. This is, depending on the property considered (compressive strength, water permeability, carbonatation, and so on) regarding to a particular addition (siliceous fly ash, silica fume or blast-furnace slag) taking into account the production conditions (concrete mix design, concreting, compactness, curing and so on), the $k$-value will have different values. This fact leads to set up safe and conservative $k$-values in standards and national regulations. The establishment of an upper limit for $k$-values allows their use by any engineer and technician in an easy and, more importantly, safe way.

\section{DISCUSSION ON THE K-VALUES FOR GROUND GRANULATED BLAST-FURNACE $S L A G$ (GGBS)}

\subsection{K-value regarding compressive strength}

The $k$-value regarding the concrete compressive strength range is quite wide because it depends on the cement content and curing conditions among other factors.

The ground granulated blast-furnace slag (ggbs) kvalues decrease significantly when the addition content increases. Thus, the $k$-value increases with the cement content. This fact is logical because the cement acts as an activator. Firstly, the calcium silicates of the Portland clinker react with the water during the hydration process releasing calcium hydroxide $\mathrm{Ca}(\mathrm{OH})_{2}$, and secondly, the alkaline ions from the clinker go to the concrete pore solution. The calcium hydroxide is involved in the pozzolanic reactions and the alkalis $\left(\mathrm{Na}^{+}, \mathrm{K}^{+}\right)$promote the partial alkaline activation of the ground granulated blast-furnace slag.

A maximum threshold value of cement replacement by the addition is given in the literature because the $k$ value decreases when such threshold level is reached. Some authors set up this maximum replacement content in $50 \%$ for ground granulated blast-furnace slag (ggbs).

Figure 1 shows the concrete compressive strength results along the time. These concretes were made of $0 \%, 30 \%, 50 \%, 70 \%$ and $85 \%$ ggbs (3). It is observed a significant possitive effect of the ground granulated blast-furnace slag addition when is added in the range of $30 \%-50 \%$ by weight.

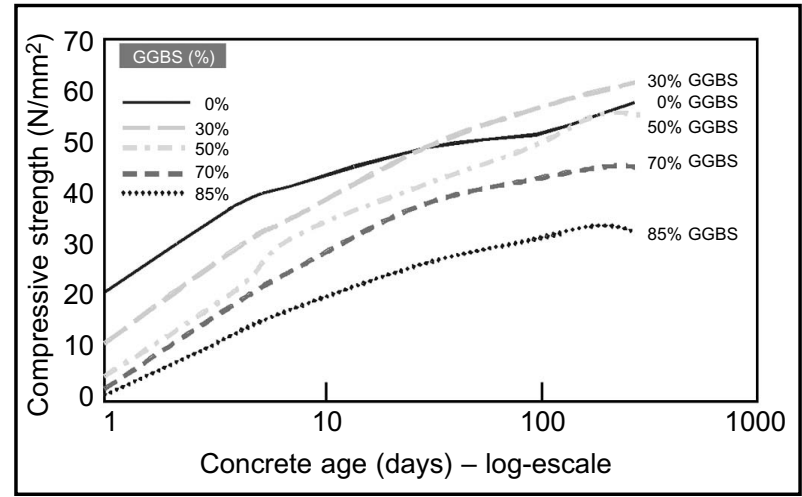

Figure 1. Compressive strength evolution with time with regard to ggbs content (3). 


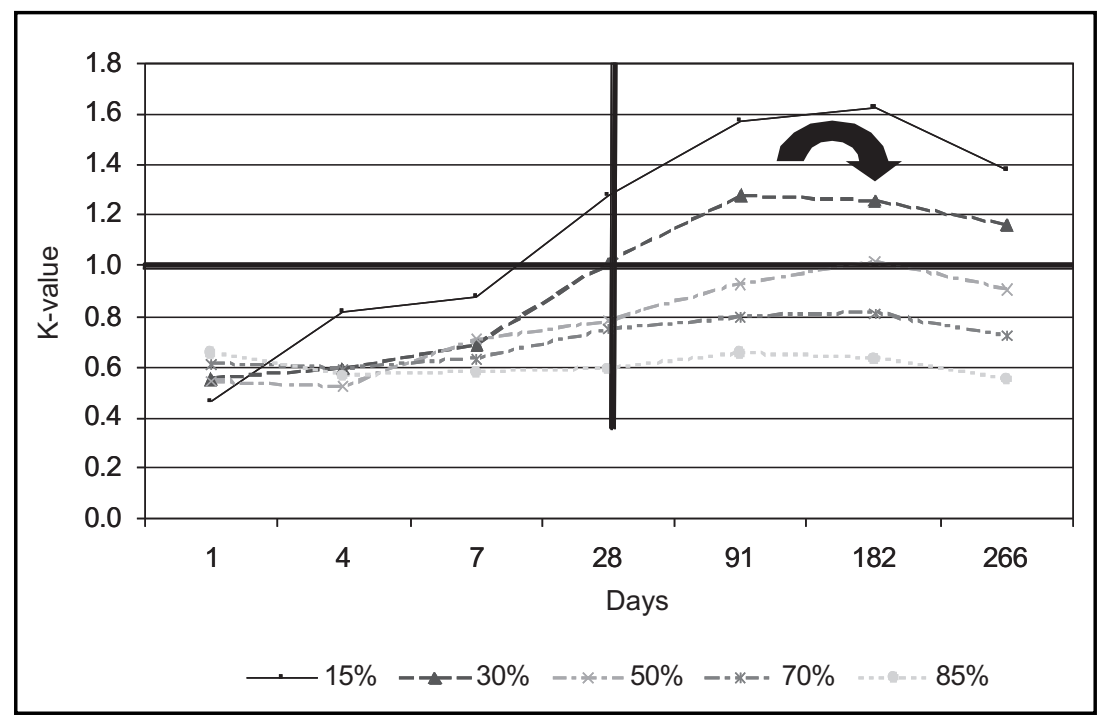

Figure 2. $k$-value evolution along the time with regard to the ggbs content (3).

On the other hand, Figure 2 shows the $k$-values calculated from data shown in Figure 1. As it can be observed, at 28 days only low ggbs contents (15\% and $30 \%$ ) give $k$-values above 0.8 (1.28 and 1.01, respectively). For all the cases, the $k$-value increases with the time until 3-6 months, and then, it decreases reaching again similar values to those obtained at 28 days or even lower than those as it happens with cement replacement of $70 \%$ and $85 \%$ by ggbs.

It is quite important to take into account, when these results are analysed, that all the concretes have been well-cured. In real curing conditions, when a proper wetcuring cannot be guaranteed, these $k$-values related to the compressive strength will be even lower as will be shown in the next section. This is due because of concretes made of ground granulated blast-furnace slag are more sensitive to a bad curing than concretes made without additions.

\subsection{Curing effect on ground granulated blast-furnace slag $k$-value}

It is well-known that durable and mechanical properties of blended concretes with ground granulated blastfurnace slag are more sensitive to a bad curing than similar concretes without additions (4).

Figure 3 compares the effect of curing time (1, 3, 7 and 28 days) and the curing conditions ( $C$ : curing in a bag and W: water curing) in concretes without additions and in concretes having $50 \%$ of ground granulated blastfurnace slag with regard to water permeability. It can be observed clearly that curing times of 1-day and 3-days (C) are not enough in order to achieve better results in ggbs concretes than in concretes without addition.
Moreover, wet curing times of 7 and 28 days (W: water curing) are necessary to guarantee a lower water permeability; however, such long time periods of curing are not usual in practice, therefore, it is recommendable to advise and specify a minimum period of curing time in wet conditions of 7-days when ggbs concretes are employed.

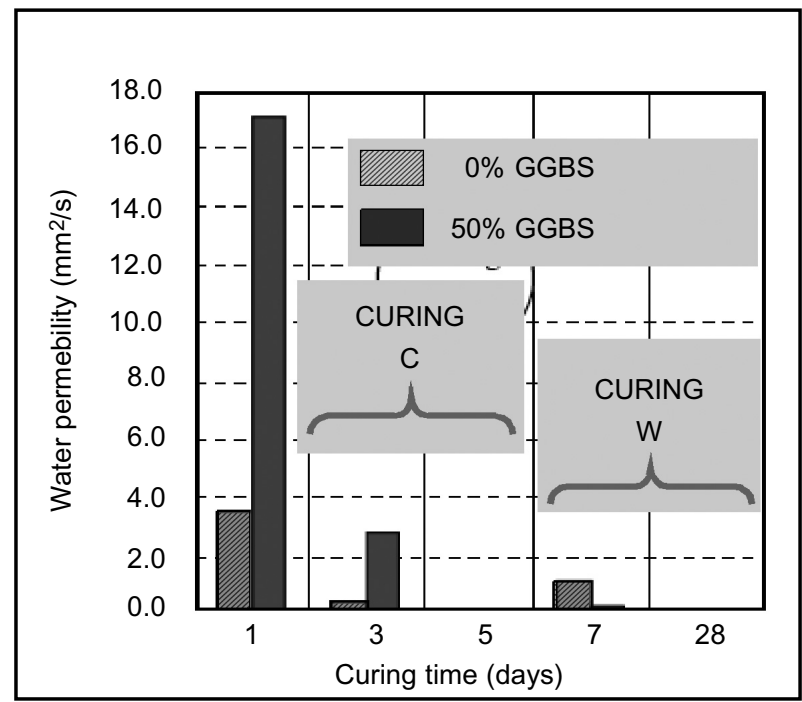

Figure 3. Curing effect on the water permeability of concretes with or without $50 \%$ of ground granulated blast-furnace slag (4).

One the other hand, Figure 4 shows the effect of different curing types identified with the codes D1, CD3, CD5, CD7, C28, WD3, WD5, WD7, WD28, S3, S7 and $S 28$ in a concrete without addition in comparison to another containing a $50 \%$ by weight of ggbs. Letters indicate the curing conditions ( $C, D$ and $C D$ : curing in mould and bag; $W$ and WD: water curing and S: sealed 


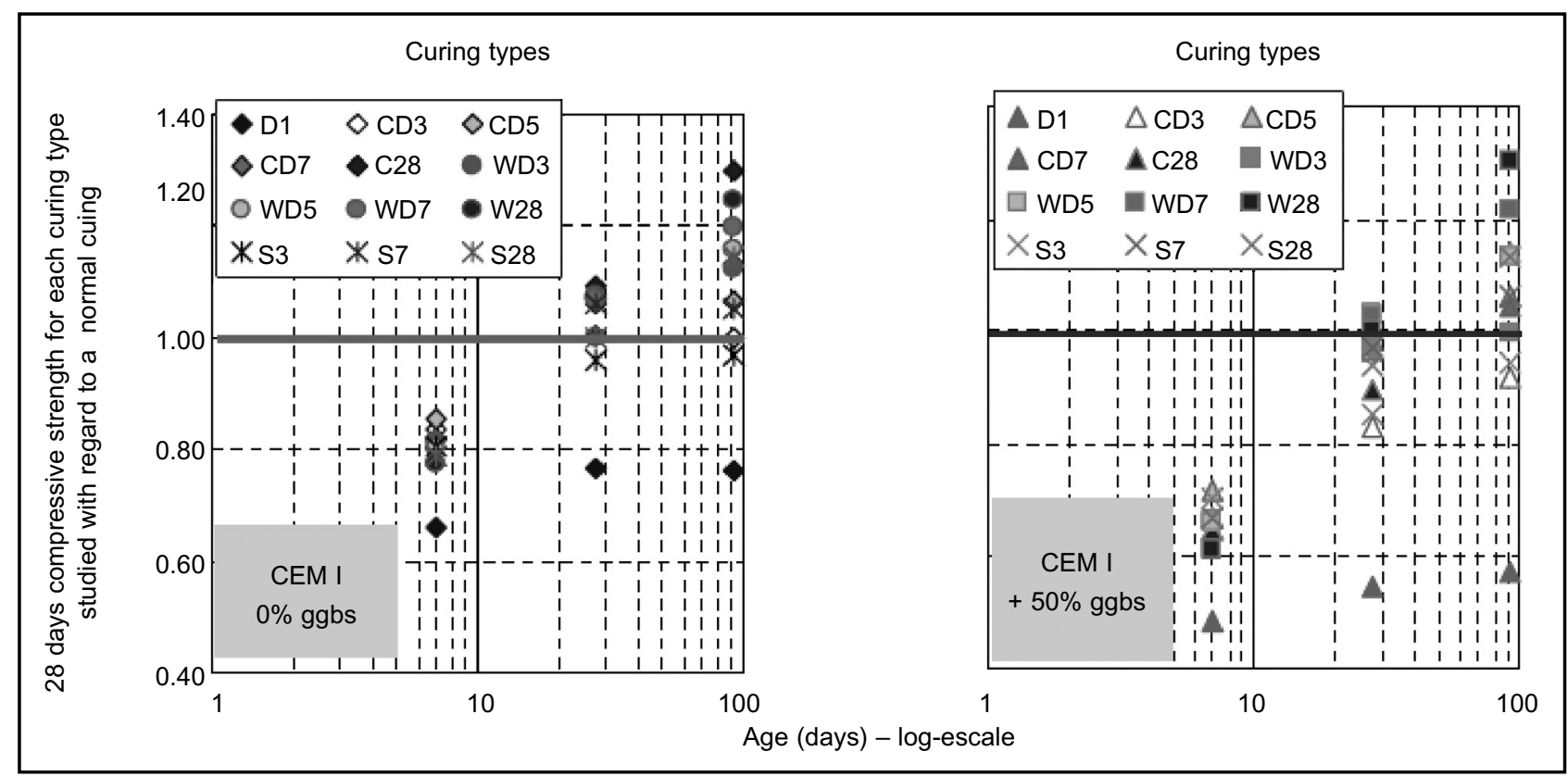

Figure 4. Curing effect on compressive strength of concretes without addition (left) or with $50 \%$ of ground granulated blast-furnace slag addition (right) (4).

curing) and the number after the letter shows the time of curing in days. The unity corresponds to the 28-days compressive strength of a concrete subjected to curing conditions considered as normal. After curing, the specimens were hold at $20^{\circ} \mathrm{C}$ and $60 \% \mathrm{RH}$ until testing. It is quite evident that a bad curing, i.e. low humidity and a short period of curing time, affects more negatively to a ggbs concrete than to a plain concrete without any direct addition incorporated. For instance, a D1 curing (one day in mould and later at 60\% RH until 28-days compressive strength testing) provides only an $80 \%$ of the strength reached with a normal curing in concretes without any addition; on the contrary, this percentage of decrease is quite lower (60\%) when $50 \%$ of ground granulated blast-furnace slag are added to the concrete.

Summing up, Figure 4 exhibits a narrower band of results for the concrete without addition than for the concrete with a cement replacement of a $50 \%$ by ggbs. This fact demonstrates that ggbs concretes are more sensitive to a bad curing than concretes without any direct addition. In particular, at high curing temperatures in ggbs concretes with over $50 \%$ ggbs replacement $\left(175^{\circ} \mathrm{C}\right.$ and $0.5 \mathrm{MPa}$ in autoclave and $80{ }^{\circ} \mathrm{C}$ vapour curing), a negative effect of loss of compressive strength is observed (5).

Also, a low humidity curing at $65 \% \mathrm{RH}$ in ggbs concretes may result in a compressive strength decrease of about $15 \%$ compared to the compressive strength obtained at $100 \%$ RH (6). In addition, it has been established that the effects of curing on ggbs concretes are more significant with the increase of the water/cement ratio. With regard to the concrete placing and curing temperatures, it can be said that high concreting temperatures, generally, might not be recommendable due to an adverse effect on the initial curing of ggbs concrete related to a possible loss of water in some cases. However, it could provide a wet curing, and also such high temperatures increase the hydration rate. In this way, Figure 5 shows the effect of both casting and curing temperatures on compressive

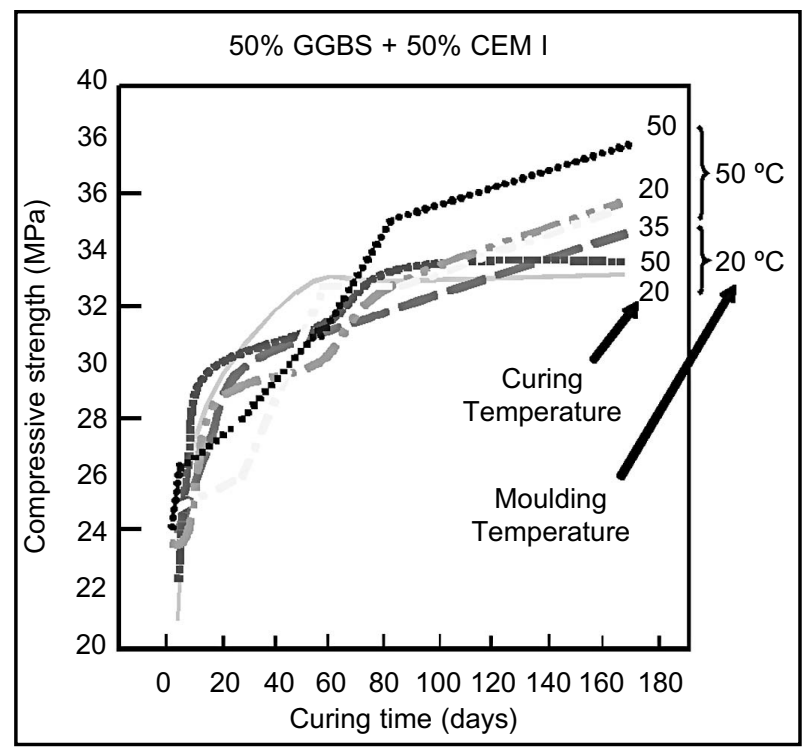

Figure 5. Effect of the moulding temperature $\left(20^{\circ} \mathrm{C}\right.$ and $\left.50^{\circ} \mathrm{C}\right)$ and the curing temperature $\left(20^{\circ} \mathrm{C}, 35^{\circ} \mathrm{C}\right.$ and $\left.50^{\circ} \mathrm{C}\right)$ on the 28-days compressive strength of concretes with $50 \%$ of ggbs and $50 \%$ of CEM I (7). 
strength of a concrete with $50 \%$ of ground granulated blast-furnace slag and $50 \%$ of CEM I (7).

Curing time as well as type of curing are two determining parameters of concrete microstructure. Therefore, the higher curing humidity, the higher concrete compactness, i.e. the lower total porosity (Figure 6). The pore size distribution also will present a lower amount of capillary pores and, in general, the average pore size will be thiner; these results will promote improved mechanical and durable characteristics (8).

Strictly speaking, it can be concluded that the k-value decreases dramatically when the curing time in wet conditions is short.

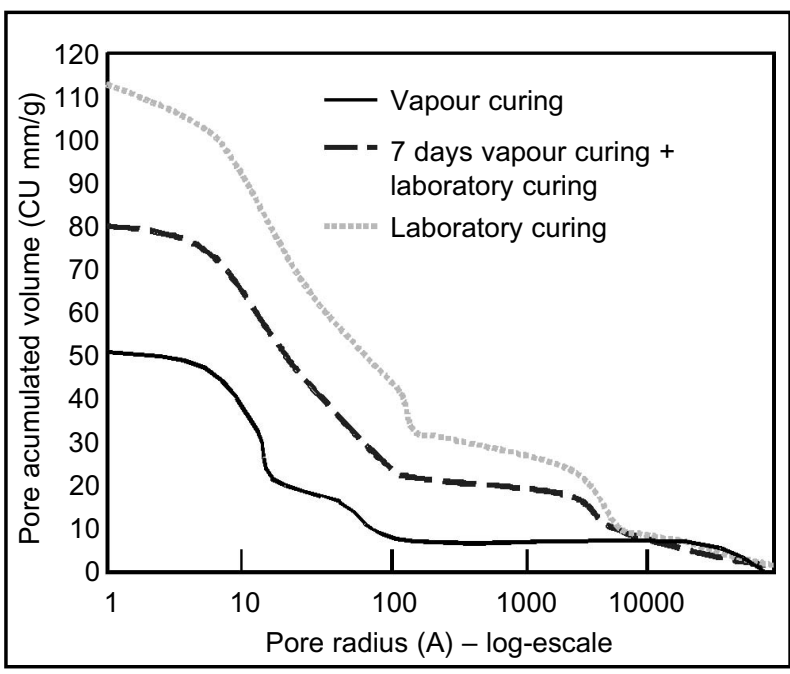

Figure 6. Drying effect on the pore size distribution of a concrete with $65 \%$ of ggbs after 6 months (8).

\subsection{K-value with regard to concrete carbonation}

The carbonation coefficient generally increases with the amount of cement replacement by ground granulated blast-furnace slag. However, below $15 \%$ of cement replacement, the carbonation rate of ggbs concretes is similar to that of the reference concretes (9). Figure 7 shows the carbonation coefficients, $A$, related to concretes with $0 \%$ and $50 \%$ of ground granulated blastfurnace slag (9). The highest carbonation rate is obtained in the concrete with $50 \%$ of ggbs and the lowest in concretes without addition for all the range of water/binder ratios studied $(0.4,0.5,0.6$ and 0.7$)$. However, the difference found between the carbonation coefficient, A, of concretes with (50\% slag) or without addition is quite variable which depends on the water/binder used. This is, a water/binder of 0.4 provides a concrete carbonation coefficient 4.5 times higher when ggbs is used in relation to concretes without addition. For water/binder ratios of 0.5, 0.6 and 0.7 such carbonation coefficients are 1.3, 1.9 and 1.3 times higher, respectively, in ggbs concretes than in plain concretes. Therefore, it is not possible to establish an unique $k$-value regarding to the carbonation of ground granulated blast-furnace concretes without taking into account the water/binder ratio used in the concrete, the ggbs content and the curing conditions in each case.

These data fit to those found in real structures (Figure 8), where the highest carbonation depth is found at indoor conditions sheltered from the rain while in outdoor conditions, where wet-dry cycles are produced the carbonation depth is always lower. In any case, the

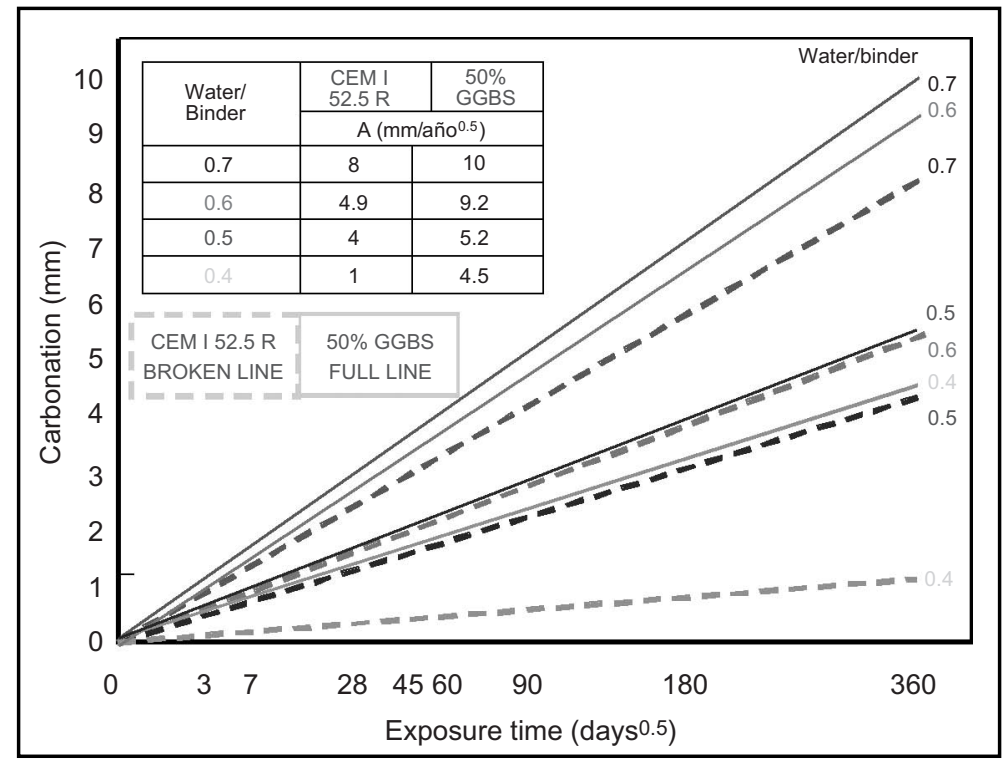

Figure 7. Carbonation coefficient of concretes with $0 \%$ and $50 \%$ of ggbs (9). 


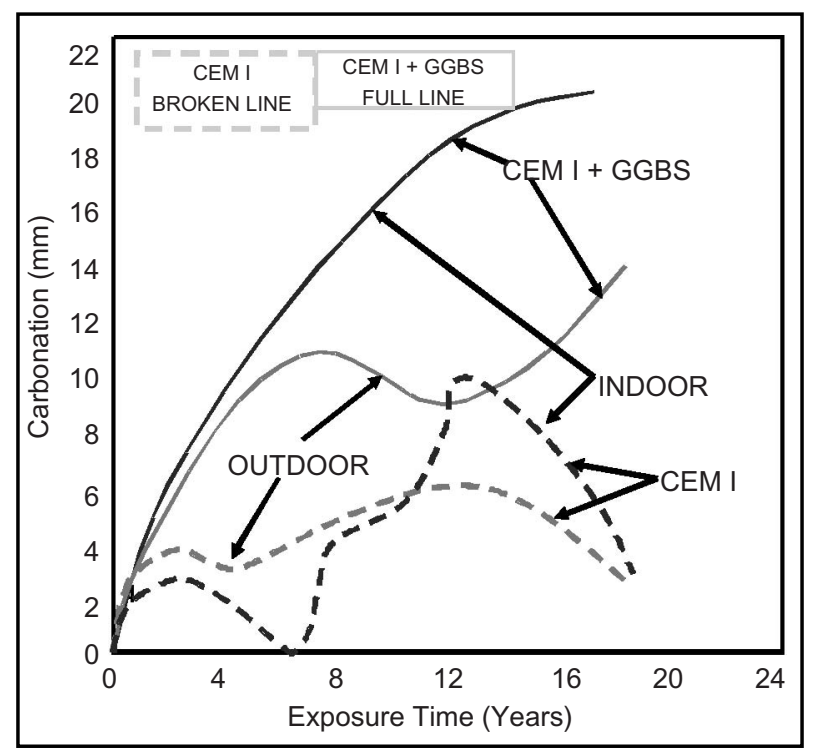

Figure 8. Carbonation effect on real concrete structures with and without ggbs exposed to indoor and outdoor conditions (10).

fastest carbonation rate is produced, in ggbs concretes exposed to dry environments (10). These data are a consequence of the higher capillary porosity found in ggbs concretes (Figure 9). These results show that curing conditions in real structures are quite different to the required curing conditions for ggbs concretes (longer periods of curing time are needed).

Finally, Figure 10 shows that even 28-days cured concretes with a high slag content (more than 66\% slag) are more carbonated than concretes without any addition made of CEM I with water/cement ratios of 0.42 and 0.60 due to the higher alkaline reserve of the last ones (11).

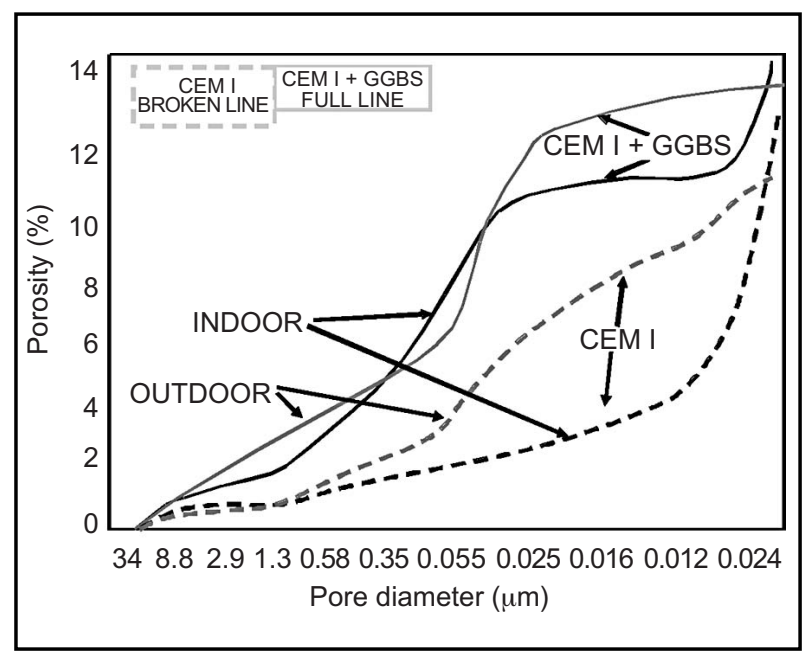

Figure 9. Porosity measured in real concrete structures with and without ggbs exposed to indoor and outdoor environments (10).

\subsection{K-value regarding to chloride ion diffusion into concrete}

Ground granulated blast-furnace slag concretes well-cured present very low chloride diffusion coefficients. Such coefficients decrease with the amount of ground granulated blast-furnace slag up to a replacement threshold value.

During the hydration of ggbs concretes gels capable of reducing the chloride ions penetration through the concrete are formed. Therefore, in similar conditions, a ggbs concrete can prevent more efficiently the chloride ingress into the reinforced concrete than a concrete without ggbs.

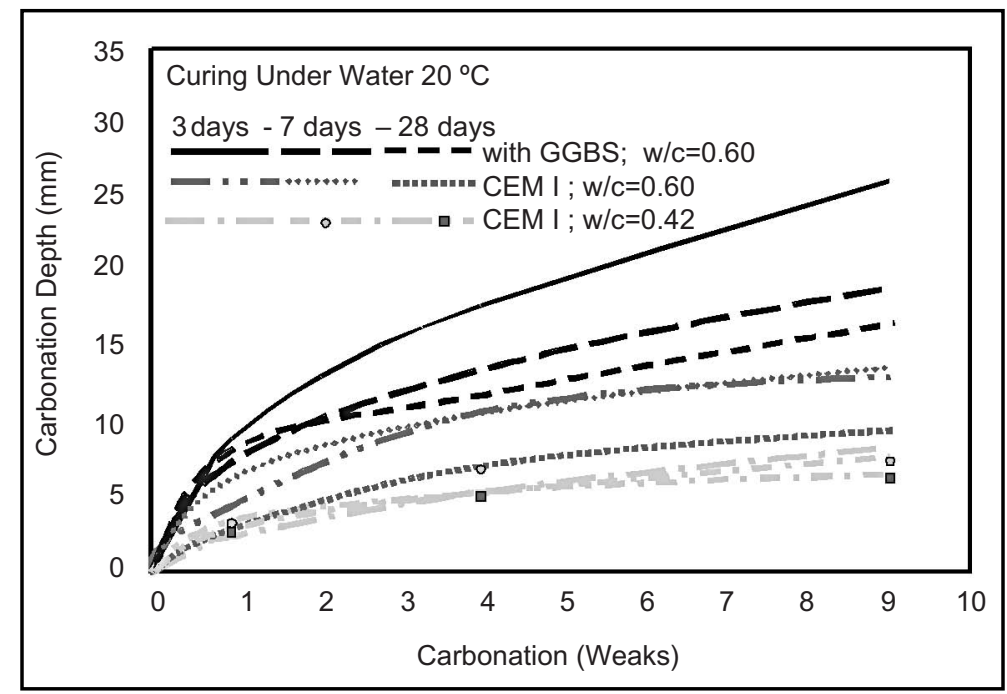

Figure 10. Carbonation depths of concretes made of CEM I with and without ground granulated blast-furnace slag (11). 


\subsection{K-value of ggbs concretes exposed to frost-thaw cycles}

In ground granulated blast-furnace slag concretes cured less than 7-days or with an insufficient wet-curing, a lower frost-thaw resistance than in reference concretes without addition has been reported. In general, it can be said that usual frost-thaw cycles occurred in highways (highways environment) are more deleterious than those produced in marine environments. In addition, airentraining agents are very low efficient in ggbs concretes with $30 \%$ of ground granulated blast-furnace slag (Figure 11). Thus, ggbs concretes are more sensitive to cold environments where frost-thaw cycles may be produced (12).

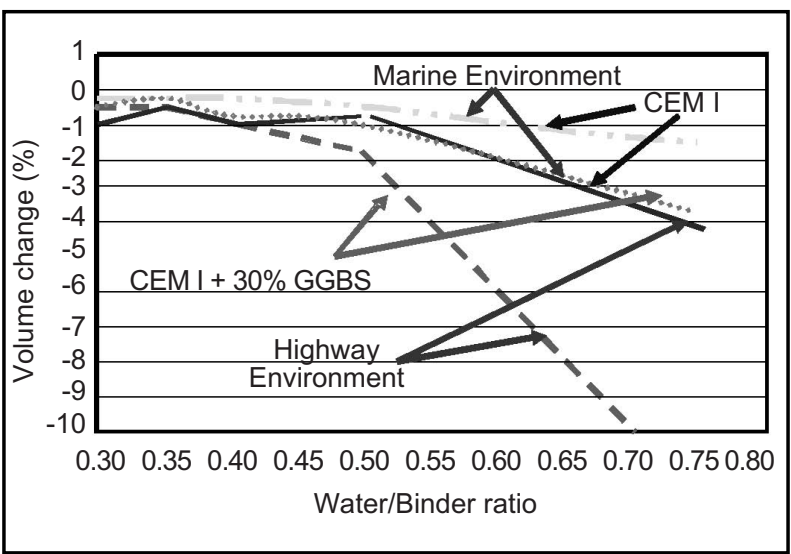

Figure 11. Frost-thaw resistance of concretes exposed to highway and marine environments with air-entraining agent (12).

The mentioned above effects are quite insignificant with water/binder rations below 0.45 and they become dramatically deleterious above 0.50. In the concrete without air-entraining agent (Figure 12) the negative effect gets worse in highway environment, particularly in concrete without additions. However, in the marine environment there is no a significative difference between concretes with or without air-entraining agents.

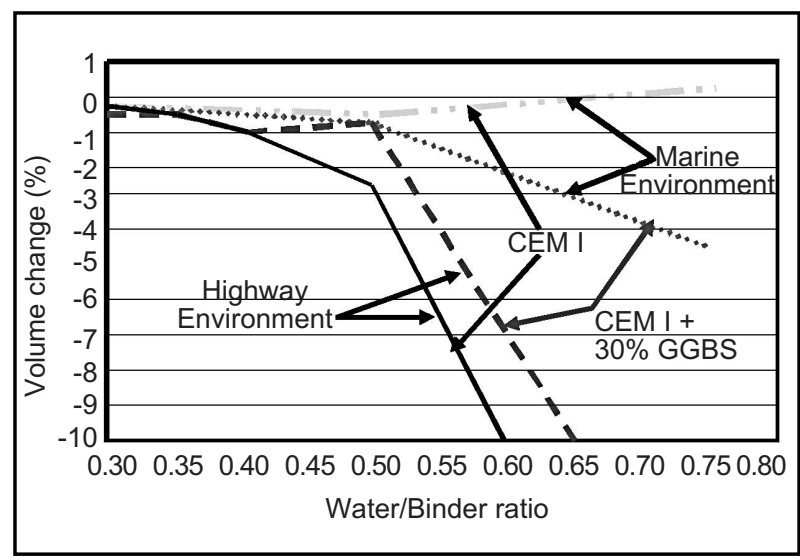

Figure 12. Frost-thaw resistance of concretes exposed to highway and marine environments without air-entraining agent (12).

On the other hand, the effect of carbonation of the concrete in the frost-thaw cycles resistance affects in a quite different way in a concrete without additions or with $65 \%$ of ground granulated blast-furnace slag (Figure 13). While the most positive situation for a plain concrete without ggbs is to be carbonated and dry, for a ggbs concrete such situation is unfavourable. On the contrary, the best condition for a ggbs concrete is to be watersaturated or completely dry but not carbonated (12).

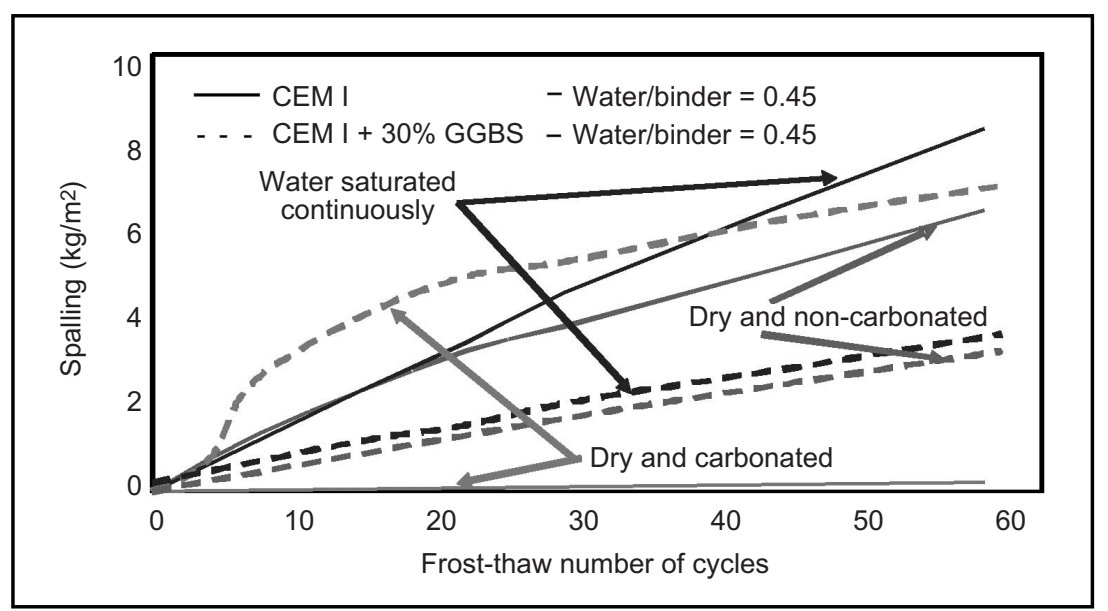

Figure 13. Frost-thaw resistance of concretes without and with a $65 \%$ of ggbs in wet/dry and arbonated/uncarbonated environments (12). 
Figure 14 shows the higher residual expansion found in ggbs concretes subjected to frost-thaw cycles with regard to plain concretes without ggbs (10). Regarding to the concrete spalling produced by frost-thaw cycles, it can be said in general, that it increases with the ground granulated blast-furnace slag content (Figure 15); however, it is possible to find a higher 28days compressive strength when increasing the ggbs content (13). This fact shows, once again, that a ground granulated blast-furnace slag $k$-value for the compressive strength is not valid regarding durable properties, as for instance, frost-thaw cycles resistance.

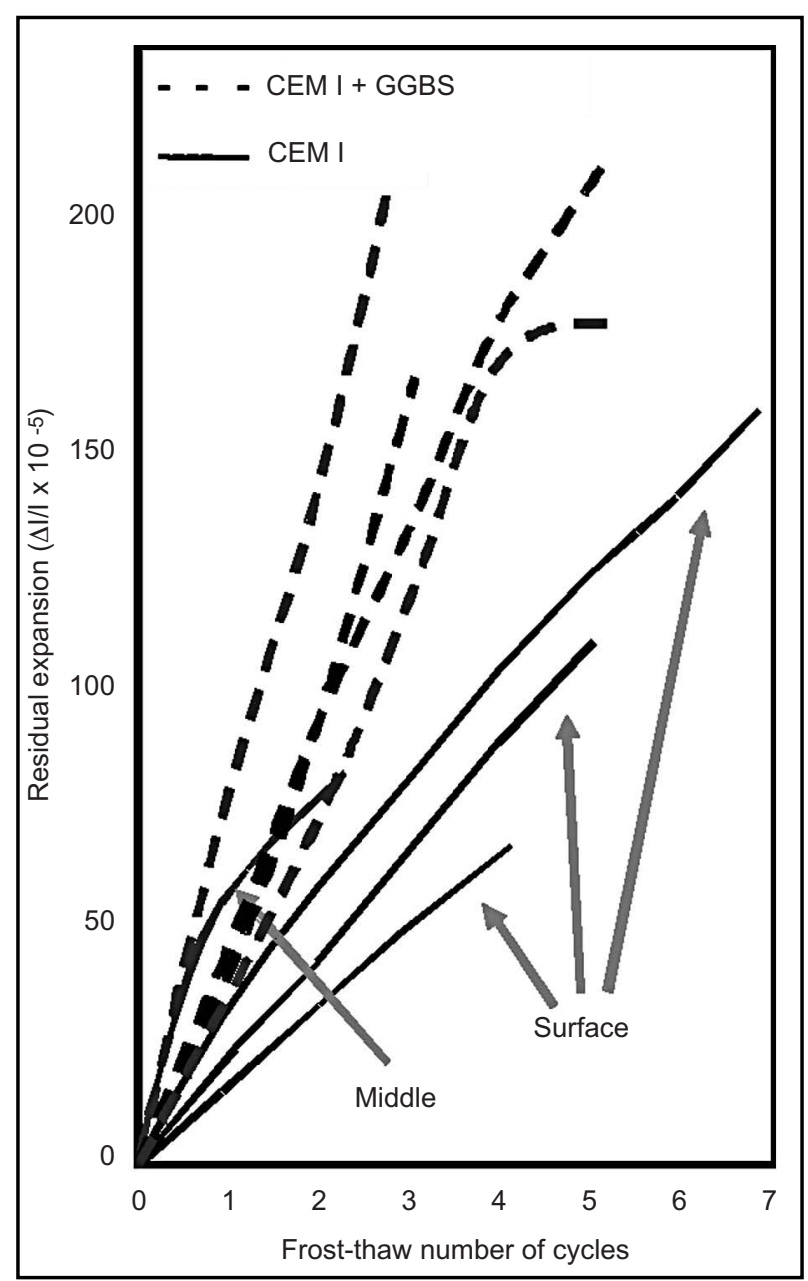

Figure 14. Residual expansion of concrete specimens without addition (CEM I) and with addition of ground granulated blast-furnace slag (CEM I+ ggbs) in relation to the number of frost-thaw cycles (10).

\subsection{K-value regarding abrasion resistance of ggbs concretes}

A lower abrasion resistance has been found in ground granulated blast-furnace slag concretes than in plain

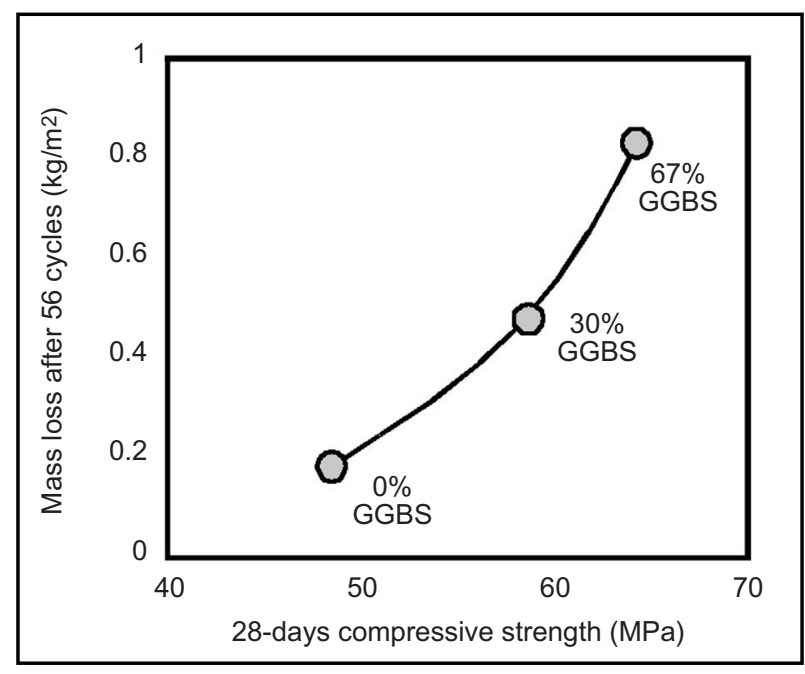

Figure 15. Frost-thaw resistance expressed as weight loss after 56 cycles with regard to the 28-days compressive strength (13).

concrete without addition, both of them subjected to a bad-curing.

It could be said that a ggbs addition up to $45 \%$ has a slight beneficial effect on the abrasion resistance (14). However, with higher ggbs contents, such effect is inverted to a deleterious one. This negative effect is stronger when the curing is getting worse (Figure 16). As it happens for all the characteristics related to ggbs concretes, an important factor to take into account is the water/binder ratio (Figure 17).

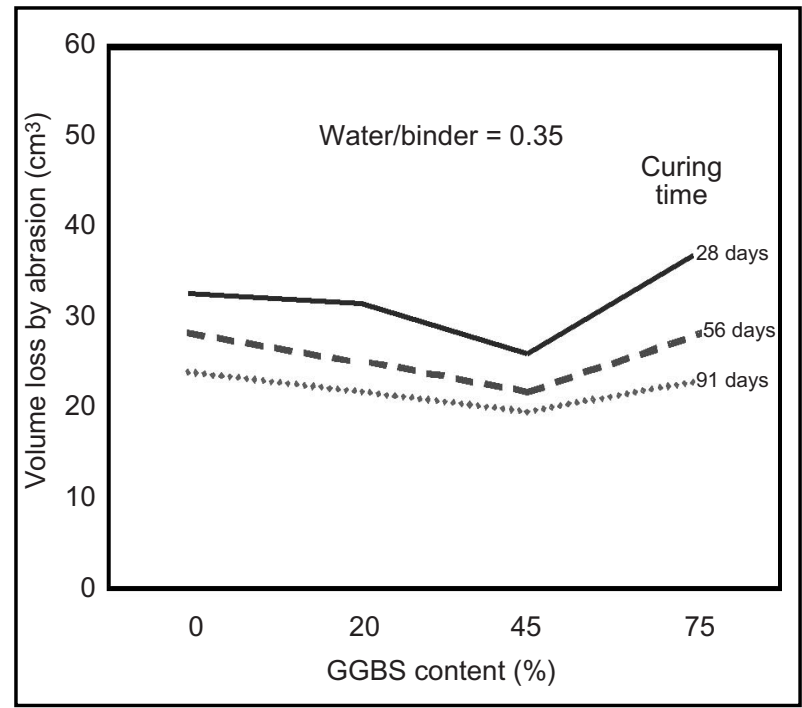

Figure 16. Abrassion resistance of a concrete with a water/binder ratio of 0.35 in function $o$ $f$ the blast-furnace slag content after 3 hours of testing (14). 


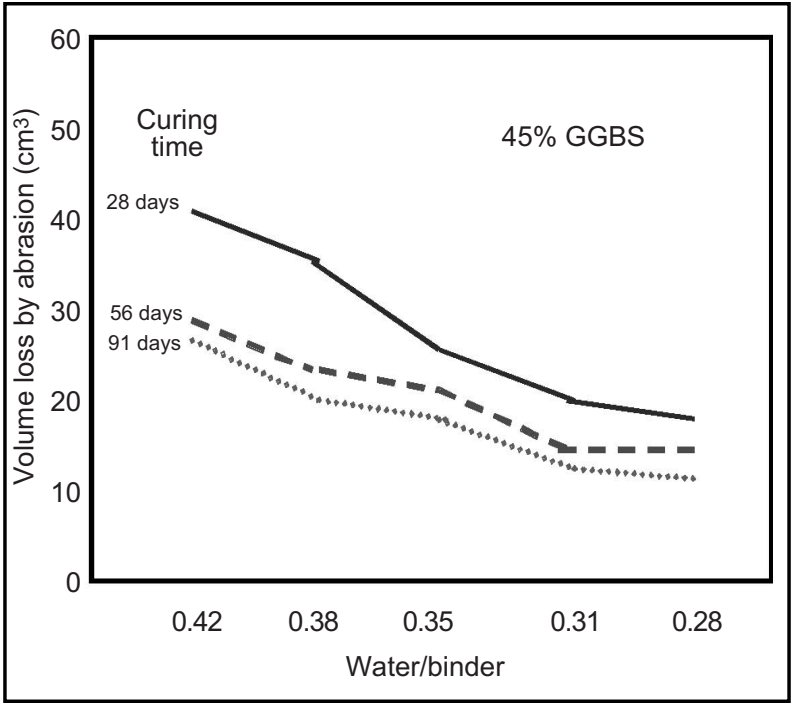

Figure 17. Abrassion resistance of a concrete made of a $45 \%$ of blast-furnace slag with regard to the water/binder ratio (14).

\section{CONCLUSION}

The possibility of having a $k$-value for ground granulated blast-furnace slag (ggbs) is very attractive because it leads to an easy way of adding them directly to the concrete (15). However, summing up all the results showed in the present paper, it can be concluded that there is not an unique and universal $k$-value. Therefore, a quite wide range of $k$-values can be found in the literature depending on:

a) Type and characteristics of the ground granulated blast-furnace slag.

b) Mix design and type of concrete.

c) Curing conditions (moisture and time).

d) Performance considered (Mechanical strength -28days compressive strength- or durability -carbonation, frost-thaw cycles resistance, and so on-).

In conclusion, setting up only a general $k$-value is complex and risky; this is the reason that justifies that all the recommended $k$-values in international standards and national practice rules must be prudent and established according to a safety criteria, and then, it is not a good criteria to set real $k$-values obtained in particular cases but not always reproducibles.

On the other hand, it is necessary to take into account that although the $k$-value is a practical and useful tool recognized in the European standard EN 206-1:2000 and several concrete national rules and regulations as the Spanish one (EHE-08), the basic principles of the interactions of the ggbs in the concrete do not allow the characterisation of such addition, with only one universal $k$-value. This is, depending on the property considered (Compressive strength, carbonation, frostthaw cycles, and so on) and the production conditions (mix design, placing, curing and so on), the $k$-value will have different values. Therefore, the reference $k$-values to be presented in standards and national rules and regulations must be set up from a safety criteria as it was explained previously.

In particular, when ground granulated blast-furnace slag (ggbs) is going to be used is necessary to take into account the following points:

- The $k$-value decreases when the amount of ggbs increases. This reduction from $35 \%$ and $55 \%$ of ggbs with a water/binder ratio of 0.4-0.5 could reach half$k$-value.

- The $k$-value increases with the ggbs finesses due to the higher specific surface and then the higher ggbs reactivity.

- Apparently, the $k$-value is higher when ggbs is added to low strength class cements i.e. a ground granulated blast-furnace slag will have a higher $k$-value with a CEM I 42.5N than with a CEM I 52.5R.

- The mechanical and durable properties of a ground granulated blast-furnace slag concrete are very sensitive to a bad curing, particularly the durable ones. Therefore, the $k$-value must be obtained experimentally considering the usual curing conditions in the application site. This is, each country should decide the most adequate $k$-values and collect them in the national standards or national concrete regulations.

- Although ground granulated blast-furnace slag concretes present good mechanical and durable characteristics in general, in some cases as frostthaw cycles resistance and carbonation, they could present a worse durability than concretes without any addition, particularly, when the concrete is cured with low moisture or the curing time has been not enough lasted.

- A conservative approach is required when the $k$-value is to be set up in the standards and concrete codes until more research data would be obtained. The authors propose a starting $k$-value equal to that for the fly ashes ( $k$-value $=0.4$ ), which could be increased with more experimental data and practical experience. Moreover, a percentage of ggbs higher than 30\% added directly to a concrete should be studied case by case due to the great variability of $k$-values found in the literature.

\section{ACKNOWLEDGEMENT}

The authors are very grateful to Olga Hernández Fernández for her great patience and dedication editing the present paper. 


\section{BIBLIOGRAPHY}

(1) EN 206-1:2000. Concrete - Part 1: Specification, performance, production and conformity. CEN/TC 104. + Resolutions of the CEN/TC 104/SC 1 (Delft 2010-09-15/16).

(2) EHE-2008. Instrucción de Hormigón Estructural. Real Decreto 1247/2008, de 18 de julio, por el que se aprueba la instrucción de hormigón estructural (EHE-08). (C) Ministerio de Fomento. Spain.

(3) Gruyaert, E.: "Hydration heat and strength development of concrete containing blast-furnace slag", Ghent University, Belgium.

(4) Iyoda, T.; Dan, Y.; Sagawa, Y.; Hamada, H.: "The effect of curing period on the durability of concrete using blast-furnace slag blended cement". The $3^{\text {rd }}$ ACF International Conference-ACF/VCA 2008.

(5) Aldea, C. A.; Young, F.; Wang, K.; Shah, S. P.: "Effects of curing conditions on properties of concrete using slag replacement", Cem. Concr. Res., Volume 30, Issue 3, March 2000, pp. 465-472. doi:10.1016/S0008-8846(00)00200-3

(6) Atiș, C. D.; Bilim, C.: "Wet and dry cured compressive strength of concrete containing ground granulated blast-furnace slag", Building and Environment, volume 42, Issue 8, August 2007, pp. 3060-3065.

(7) Ballim, Y.: "Curing and the durability of opc, fly ash and blast-furnace slag concretes". Materials and Structures/Materiaux et Constructions, May 1993, vol. 26, no. 158, pp 238-244.

(8) Bouikn,i A.; Swamy, R. N.; Bali, A.: "Durability properties of concrete containing $50 \%$ and 65\% slag". Construction and Building Materials 23 (2009) 2836-2845. doi:10.1016/j.conbuildmat.2009.02.040

(9) Collepardi, M.; Collepardi, S.; Ogoumah Olagot, J. J.; Simonelli, F.: "The influence of slag and fly ash on the carbonation of concrete". Eighth CANMET/ACI Int. Conf. on fly ash, silica fume, slag, and natural pozzolans in concrete. Proccedings ACI SP-221-29. Las Vegas, Nevada, USA. 2004. 23-29 de mayo de 2004, pp. 483-493.

(10) Litvan, G. G.; Meyer, A.: "Carbonation of granulated blast furnace slag cementconcrete Turing twenty years of field exposure". Second Int. Conf. On fly ash, silica fume, slag, and natural pozzolans in concrete. Proccedings ACI SP-91, Madrid, Spain, 1986, pp. 14451462.

(11) Sisomphon, K.; Franke, L.: "Carbonation rates of concretes containing high volume of pozzolanic materials". Cem. Concr. Res., 37 (2007) 1647-1653. doi:10.1016/j.cemconres.2007.08.014

(12) Utgenannt, P.; Luping, T.: CBI - Swedish Cement and Concrete Research Institute. Experience from field exposure in marine and highway environment - Frost resistance, chloride ingress and reinforcement corrosion. 10 years of frost experience at 3 Swedish field exposure sites. Peter Utgenannt (Swedish Cement and Concrete Research Institute, CBI). Erika Holt, Hannele Kuosa, Markku Leivo \& Erkki Vesikari. DuraInt-Project Workshop. Effect of interacted deterioration parameters on service life of concrete structures in cold environments. VTT WORKING PAPERS 116. ISBN 978-951-38-7177-2. March 2009. 32 p. VTT Technical Research Centre of Finland. P.O. Box 1000, FI-02044 VTT, Finland.

(13) Giergiczny, Z.; Glinicki, M. A.; Sokolowski, M.; Zielinski, M.: "Air void system and frost-salt scaling of concrete containing slagblended cement". Construction and Building Materials 23 (2009) 2451-2456. doi:10.1016/j.conbuildmat.2008.10.001

(14) Wu, C. H.; Yen, T.; Liu, Y. W.; Hsu, T. H.: "The abrasion erosion resistance of concrete containing blast furnace slag".

(15) Härdtl, R. T.: "The application of the k-value concept to ground granulated blast furnace slag". Cement International, 6/2010. vol. 8., pp. 66-73. 